\title{
EVALUATION OF ETEST AND MACRODILUTION BROTH METHOD FOR ANTIFUNGAL SUSCEPTIBILITY TESTING OF Candida sp STRAINS ISOLATED FROM ORAL CAVITIES OF AIDS PATIENTS
}

\begin{abstract}
SUMMARY
A comparison of the Etest and the reference broth macrodilution susceptibility test for fluconazole, ketoconazole, itraconazole and amphotericin B was performed with 59 of Candida species isolated from the oral cavities of AIDS patients. The Etest method was performed according to the manufacturer's instructions, and the reference method was performed according to National Committee for Clinical Laboratory Standards document M27-A guidelines. Our data showed that there was a good correlation between the MICs obtained by the Etest and broth dilution methods. When only the MIC results at \pm 2 dilutions for both methods were considered, the agreement rates were $90.4 \%$ for itraconazole, ketoconazole and amphotericin B and $84.6 \%$ for fluconazole of the C. albicans tested. In contrast, to the reference method, the Etest method classified as susceptible three fluconazole-resistant isolates and one itraconazoleresistant isolate, representing four very major errors. These results indicate that Etest could be considered useful for antifungal sensitivity evaluation of yeasts in clinical laboratories.
\end{abstract}

KEYWORDS: Etest; Broth macrodilution; Antifungal susceptibility tests.

\section{INTRODUCTION}

Unlike antibacterial assays, standardized methods for testing antifungal agents are not generally available in most microbiological laboratories. Owing to the increased fungal infection rates in immunocompromised patients, including those with AIDS and recipients of solid organ transplants and cytotoxic chemotherapy, have created new challenges in the area of antimicrobial drug therapy, much effort has been undertaken to obtain a standardized rapid and reliable routine

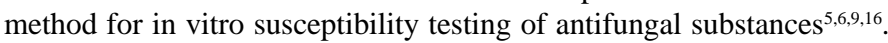
So, the publication in 1992 by the National Committee for Clinical Laboratory Standards (NCCLS) ${ }^{10}$ of the proposed broth macrodilution reference for yeast, NCCLS M27-P document, which was moved to the tentative level, or M27-T, in $1995^{11}$ and the NCCLS M-27 A in $1997^{12}$, documents are an important landmark in the field of testing antifungal susceptibilities. This method provides guidelines for testing the antifungal susceptibilities of Candida spp and Cryptococcus neoformans and shows interpretative breakpoints in susceptible, dose dependent and resistant for Candida species against itraconazole, fluconazole and flucytosine (NCCLS, 1997) ${ }^{12}$.

The Etest (AB Biodisk, Solna, Sweden) is now well established as an excellent method for in vitro testing of antimicrobial agents against numerous microbial pathogens and the adaptation to in vitro susceptibility testing of fungi has also met with reasonable success ${ }^{1,2,8,18,20}$. This method is based on the diffusion of a continuous concentration gradient of the antifungal agent tested from a plastic strip into an agar medium. Since these strips contain a predefined continuous grade of a drug, it is possible to obtain reproducible quantitative MIC readings ${ }^{13,18}$.

In the present study, we compared a broth macrodilution assay, performed in accordance with NCCLS guidelines, and Etest method by determining the MICs of four antifungal agents for 59 clinical isolates of yeasts pathogenic isolated from patients with AIDS.

\section{MATERIALS AND METHODS}

Organisms: Fungal isolates were obtained from 86 swabs of the oral mucosa from AIDS patients during the initial diagnosis of candidiasis infections who were attended in the Hospital de Doenças Tropicais de Goiânia (HDT) from January to December 2000. Swabs were streaked for isolation onto Sabouraud dextrose agar (SDA) and the yeasts isolated were identified by standard methods ${ }^{7}$. Fifty nine isolates belonged to the genus Candida; of these $88.1 \%$ (52/59) were identified as C. albicans, $6.7 \%(4 / 59)$ as C. tropicalis and 5\% (3/59) as C. krusei. Each isolated was stored at ambient temperature until testing was performed, when were subcultured on SDA for $18-24$ hours at $35^{\circ} \mathrm{C}$ to ensure their purity and viability. These isolates were selected for susceptibility testing.

(1) Instituto de Patologia Tropical e Saúde Pública da Universidade Federal de Goiás, Goiânia, GO, Brasil.

(2) Instituto de Ciências Biomédicas da Universidade de São Paulo, SP, Brasil.

Correspondence to: Maria do Rosário Rodrigues Silva, Rua 15 nº 108, apto. 700, Setor Oeste. 74140-030 Goiânia, GO, Brazil.; E-mail: rosario@iptsp.ufg.br 


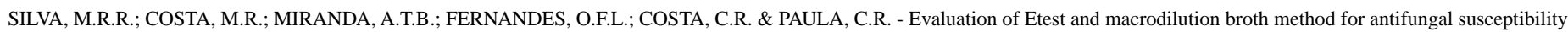
testing of Candida sp strains isolated from oral cavities of AIDS patients. Rev. Inst. Med. trop. S. Paulo, 44(3):121-125, 2002.

The test organism included American Type Culture Collection $C$. albicans (ATCC 10231) used as control in susceptibility tests.

All the isolates were tested by reference broth macrodilution method and by the Etest. The antifungal agents evaluated were amphotericin B (E.R. Squibb \& Sons), ketoconazole and itraconazole (Janssen Pharmaceuticals) and fluconazole (Pfizer, Inc., New York, N.Y). All the tests were run in duplicate.

Broth macrodilution method: The broth macrodilution method was performed by following the guidelines in NCCLS document M27-A ${ }^{12}$. It was performed in RPMI 1640 supplemented with $0.3 \mathrm{~g}$ of glutamine/ L, buffered with $34.6 \mathrm{~g}$ morpholinepropanesulfonic acid (MOPS) and adjusted $\mathrm{pH} 7.0$, contained $2 \mathrm{~g}$ of glucose. Fluconazole, ketoconazole, itraconazole and amphotericin B were obtained as reagent-grade powders from their respective manufacturers. Amphotericin B, ketoconazole and itraconazole were dissolved in dimethyl sulfoxide at a concentration of $320 \mu \mathrm{g} / \mathrm{mL}$, and fluconazole was dissolved in $0.85 \%$ saline at a concentration of $2560 \mu \mathrm{g} / \mathrm{mL}$. Stock solution were stored at $-70{ }^{\circ} \mathrm{C}$ until used. The stock yeast inoculum suspensions were adjusted to $1 \mathrm{X} 10^{6}$ to $5 \mathrm{X} 10^{6} \mathrm{CFU} / \mathrm{mL}$ by the spectrophotometric method. Briefly, an inoculum suspension was prepared for each isolate from 24 hours old cultures grown at $35^{\circ} \mathrm{C}$ and the turbidities of the resulting yeast suspension were measured with spectrophotometer at $530 \mathrm{~nm}$ and were adjusted to the percent transmission that matched a $0.5 \mathrm{Mc}$ Farland standard. The working suspension was made by a 1:100 dilution followed by a 1:20 dilution in RPMI 1640 broth medium in sufficient volume to directly inoculate each MIC tube with $0.9 \mathrm{~mL}$. Yeast inocula $(0.9 \mathrm{~mL})$ were added to each tube containing $0.1 \mathrm{~mL}$ antifungal drug solution. The range final concentration was from 0.002 to $32 \mu \mathrm{g} / \mathrm{mL}$ for amphotericin $\mathrm{B}$, ketoconazole and itraconazole and 0.016 to $256 \mu \mathrm{g} / \mathrm{mL}$ to fluconazol. The tubes were incubated at $35^{\circ} \mathrm{C}$ and were inspected after 48 hours of incubation. Drug-free and yeast-free controls were included. For the azoles, itraconazole, ketoconazole and fluconazole, the MIC was established as the lowest antifungal concentration that inhibited $80 \%$ of the control growth $(0.2 \mathrm{~mL}$ of growth control plus $0.8 \mathrm{~mL}$ of uninoculated RPMI). For amphotericin B, endpoints were determined visually by recording the lowest concentration of the agent that prevented the appearance of visible growth ${ }^{3,12}$.

Agar diffusion Etest: The Etest antifungal gradient strips were provided by the manufacturer (AB BIODISK, Solna, Sweden). RPMI agar for the agar diffusion Etest was prepared the same way as the RPMI broth and supplemented with $18 \mathrm{~g}$ of glucose/L and $15 \mathrm{~g}$ of Bacto agar/ L. The concentration gradient for itraconazole, ketoconazole and amphotericin B ranged from 0.002 to $32 \mu \mathrm{g} / \mathrm{mL}$ and the fluconazole ranged from 0.016 to $256 \mu \mathrm{g} / \mathrm{mL}$. The strips were stored at $-20{ }^{\circ} \mathrm{C}$ until use. Each solidified medium was inoculated by dipping a sterile swab into the cell suspension ( $5 \times 10^{5}$ cells $/ \mathrm{mL}$ ) and streaking it across in the surface of the agar in three directions. The plates were allowed to dry for at least $15 \mathrm{~min}$ before the Etest strip was applied to the surface. The plates were incubated at $35{ }^{\circ} \mathrm{C}$ and MICs were determined following incubation time of $24 \mathrm{~h}$. Determination of MIC endpoints by the Etest was the lowest drug concentration at which the border of the elliptical inhibition zone intercepted the scale on the antifungal strip.

Analysis of results: A total of 960 MICs for ATCC isolates and the 59 clinical yeast isolates were obtained and analyzed. Both on-scale and off-scale results were included in the analysis. The high off-scale MIC (>32 and $>256 \mu \mathrm{g} / \mathrm{mL}$ ) were converted to the next highest ( 64 and 512 $\mu \mathrm{g} / \mathrm{mL}$ ) concentration and the low off-scale (MICs $<0.002$ and $<0.016$ $\mu \mathrm{g} / \mathrm{mL}$ ) were left unchanged. Discrepancies among MIC endpoints of no more than 2 dilutions were used to calculate the percent agreement.

According to the NCCLS ${ }^{12}$ criteria, isolates for fluconazole which MICs are $\leq 8 \mu \mathrm{g} / \mathrm{mL}$ are classified as susceptible, while those for which MICs are $\geq 64 \mu \mathrm{g} / \mathrm{mL}$ are classified as resistant and isolates for which MICs are 16 to $32 \mu \mathrm{g} / \mathrm{mL}$ are termed susceptible dose dependent (SDD). Isolates for which itraconazole MICs are $\leq 0.125 \mu \mathrm{g} / \mathrm{mL}$ are classified as susceptible, while those for which MICs are 0.25 to $0.5 \mu \mathrm{g} / \mathrm{mL}$ are classified as S-DD, and those for which MICs are $\geq 1 \mu \mathrm{g} / \mathrm{mL}$ are classified as resistant.

To permit comparison between the results of the two methods, the NCCLS breakpoints were applied to both tests for these agents. Major errors were defined as results in which the reference method result was susceptible and the Etest method result was resistant, while very major errors were defined as results in which the reference method result was resistant and the Etest method result was susceptible. Minor errors were defined as variations in results from resistant to S-DD or S-DD to susceptible between the two methods ${ }^{6}$.

\section{RESULTS}

Table 1 summarizes the in vitro susceptibility (MICs) of $52 C$. albicans; 04 C. tropicalis; 03 C. krusei isolates for itraconazole, fluconazole, ketoconazole and amphotericin B by the two methods. The data are reported as the concentrations of antifungals agents necessary to inhibit $50 \%\left(\mathrm{MIC}_{50}\right)$ and $90 \%\left(\mathrm{MIC}_{90}\right)$ of the isolates tested. Itraconazole, ketoconazole and fluconazole MICs showed a broad range for all the species. Amphotericin B MICs showed a very narrow range for the species tested.

Agreement between the macrodilution method and the Etest method was good for all antifungal agents toward $C$. albicans. In contrast, the agreement among the methods was lowest for itraconazole toward $C$. krusei $(66.7 \%)$ and fluconazole, ketoconazole and amphotericin B toward C. tropicalis (75\%). With regard to fluconazole, the Etest often produced inhibition zones with difuses edges. For $25 \%$ of the $C$. tropicalis isolates growth of microcolonies with decreasing intensity just inside the border of the inhibition zone was observed. The percent of agreement between the broth macrodilution and Etest methods of the 59 isolates to amphotericin B, fluconazole, ketoconazole and itraconazole is showed in table 1. A complete agreement of Etest MIC with reference broth macrodilution method MIC was verified when the four antifungal agents were tested against C. albicans ATCC 10231.

The itraconazole and fluconazole susceptibility data are reported in Table 2. This table shows the number of isolates (for each specie) classified as susceptible (S), susceptible dose dependent (S-DD), and resistant $(\mathrm{R})$ based on the results of the two methods tested.

Table 3 details the susceptibility interpretation discrepancies between the two methods for the two drugs with NCCLS- defined breakpoints (fluconazole and itraconazole). Very major errors, in which the reference method classified an isolate as resistant and the Etest method classified 


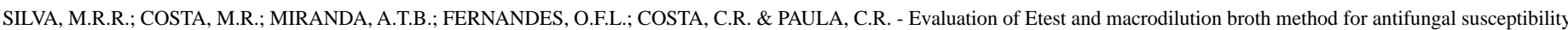
testing of Candida sp strains isolated from oral cavities of AIDS patients. Rev. Inst. Med. trop. S. Paulo, 44(3):121-125, 2002.

Table 1

Antifungal susceptibilities of 59 clinical isolates of yeasts: MIC results, agreement rate between Etest and NCCLS methods

\begin{tabular}{|c|c|c|c|c|c|c|c|c|}
\hline \multirow[b]{2}{*}{ Organism } & \multirow[b]{2}{*}{ Antifungals } & \multicolumn{3}{|c|}{ Broth macrodilution $(\mu \mathrm{g} / \mathrm{mL})$} & \multicolumn{3}{|c|}{ Etest $(\mu \mathrm{g} / \mathrm{mL})$} & \multirow{2}{*}{$\begin{array}{c}\% \\
\text { agreemen }\end{array}$} \\
\hline & & Range & $\mathrm{MIC}_{50}$ & $\mathrm{MIC}_{90}$ & range & $\mathrm{MIC}_{50}$ & $\mathrm{MIC}_{90}$ & \\
\hline \multirow{4}{*}{$\begin{array}{l}\text { C. albicans } \\
\mathrm{n}=52\end{array}$} & Itraconazole & $0.002->32$ & 0.064 & 0.50 & $0.002->32$ & 0.094 & 0.50 & 90.4 \\
\hline & Ketoconazole & $0.064->32$ & 0.25 & $>32$ & $0.064->32$ & 0.25 & $>32$ & 90.4 \\
\hline & Fluconazole & $0.19->256$ & 4.0 & $>256$ & $0.016->256$ & 3.0 & $>256$ & 84.6 \\
\hline & Amphotericin B & $0.125-2.0$ & 0.50 & 1.50 & 0.094-3.0 & 1.0 & 1.50 & 90.4 \\
\hline \multirow{4}{*}{$\begin{array}{l}\text { C. tropicalis } \\
\mathrm{n}=04\end{array}$} & Itraconazole & $0.016-0.38$ & 0.064 & 0.38 & $0.032-0.38$ & 0.064 & 0.38 & 100 \\
\hline & Ketoconazole & $0.25->32$ & 1.0 & $>32$ & $0.125->32$ & 0.38 & $>32$ & 75 \\
\hline & Fluconazole & $0.125->256$ & 1.0 & $>256$ & $0.25->256$ & 3.0 & $>256$ & 75 \\
\hline & Amphotericin B & $0.032-0.50$ & 0.50 & 0.50 & $0.064-1.50$ & 1.0 & 1.50 & 75 \\
\hline \multirow{4}{*}{$\begin{array}{l}\text { C. krusei } \\
\mathrm{n}=03\end{array}$} & Itraconazole & $0.064->32$ & 1.50 & $>32$ & $0.047->32$ & 0.064 & $>32$ & 66.7 \\
\hline & Ketoconazole & $0.125->32$ & $>32$ & $>32$ & $0.125->32$ & $>32$ & $>32$ & 100 \\
\hline & Fluconazole & $4.0->256$ & $>256$ & $>256$ & $4.0->256$ & $>256$ & $>256$ & 100 \\
\hline & Amphotericin B & $0.25-0.75$ & 0.50 & 0.75 & $0.25-1.0$ & 0.50 & 1.0 & 100 \\
\hline
\end{tabular}

Table 2

Itraconazole and Fluconazole susceptibility test results obtained with each of the two methods

\begin{tabular}{|c|c|c|c|c|c|}
\hline \multirow{3}{*}{ Species } & \multirow{3}{*}{ Classified as } & \multicolumn{4}{|c|}{ Antifungals agents/methods } \\
\hline & & & & & \\
\hline & & Macrodilution & Etest & Macrodilution & Etest \\
\hline \multirow{3}{*}{ C. albicans $(\mathrm{n}=52)$} & $\mathrm{S}$ & 37 & 36 & 42 & 46 \\
\hline & S-DD & 10 & 11 & 1 & 0 \\
\hline & $\mathrm{R}$ & 5 & 5 & 9 & 6 \\
\hline \multirow{3}{*}{ C. tropicalis $(\mathrm{n}=04)$} & $\mathrm{S}$ & 2 & 3 & 2 & 2 \\
\hline & S-DD & 2 & 1 & 0 & 0 \\
\hline & $\mathrm{R}$ & 0 & 0 & 2 & 2 \\
\hline \multirow{3}{*}{ C. krusei $(\mathrm{n}=03)$} & $\mathrm{S}$ & 1 & 2 & $\mathrm{NA}^{\mathrm{a}}$ & NA \\
\hline & S-DD & 0 & 0 & NA & NA \\
\hline & $\mathrm{R}$ & 2 & 1 & NA & NA \\
\hline
\end{tabular}

${ }^{\mathrm{a} N A}$, not applicable - Reference MIC breakpoints have not been applied to C. krusei.

Table 3

Discrepancies between test method for antifungal agents with NCCLS-defined MIC breakpoints for all organisms tested

\begin{tabular}{|c|c|c|c|c|c|c|}
\hline \multirow{3}{*}{$\begin{array}{l}\text { Organisms/ } \\
\text { antifungal agents }\end{array}$} & \multicolumn{6}{|c|}{ No. of discrepant results ${ }^{\mathrm{a}}$} \\
\hline & \multicolumn{4}{|c|}{ Minor $^{\mathrm{b}}$} & \multirow{2}{*}{$\begin{array}{l}\text { Major }^{c} \\
\text { S vs R }\end{array}$} & \multirow{2}{*}{$\begin{array}{c}\text { Very major }^{\mathrm{d}} \\
\mathrm{R} \text { vs S }\end{array}$} \\
\hline & $\mathrm{S}$ vs $\mathrm{S}-\mathrm{DD}^{\mathrm{e}}$ & S-DD vs $S$ & S-DD vs $R$ & R vs S-DD & & \\
\hline \multicolumn{7}{|l|}{ C. albicans (52) } \\
\hline Itraconazole & 3 & 2 & 0 & 0 & 0 & 0 \\
\hline Fluconazole & 0 & 1 & 0 & 0 & 0 & 3 \\
\hline \multicolumn{7}{|l|}{ C. tropicalis (04) } \\
\hline Itraconazole & 0 & 1 & 0 & 0 & 0 & 0 \\
\hline Fluconazole & 0 & 0 & 0 & 0 & 0 & 0 \\
\hline \multicolumn{7}{|l|}{ C. krusei (03) } \\
\hline Itraconazole & 0 & 0 & 0 & 0 & 0 & 1 \\
\hline Fluconazole & 0 & 0 & 0 & 0 & 0 & 0 \\
\hline
\end{tabular}

${ }^{a}$ S, susceptible; S-DD, Susceptible-dose dependent; R, resistant; ${ }^{\mathrm{b}}$ Minor difference between method were those which changed the susceptibility category from susceptible to S-DD, S-DD to susceptible, S-DD to resistant, or resistant to S-DD; ${ }^{c}$ Major differences were those in which the reference method classified isolates as susceptible and the Etest method classified isolates as resistant; ${ }^{\mathrm{d}}$ Very major differences were those in which the reference method classified isolates as resistant and the Etest method classified isolates as susceptible; ${ }^{\text {e }}$ Susceptibility results by the NCCLS method versus those by the Etest method 


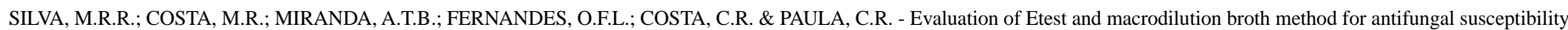
testing of Candida sp strains isolated from oral cavities of AIDS patients. Rev. Inst. Med. trop. S. Paulo, 44(3):121-125, 2002.

it as susceptible occurred for fluconazole with three C.albicans isolates and for itraconazole with one $C$. krusei isolate. The greatest percentage of minor errors was noted for itraconazole (six of the seven instances) and the one error was observed for fluconazole against $C$. albicans. Overall, the results indicated that there were only 04 (3.4\%) very major errors and $07(5.9 \%)$ minor errors between methods for all organisms tested against fluconazole and itraconazole.

\section{DISCUSSION}

Although the NCCLS broth macrodilution methods (M27-A document $)^{12}$ improved the level of interlaboratory agreement of antifungal MIC endpoint, these procedures are not convenient and efficient testing tools for the clinical laboratory. Several tests that are alternatives to the NCCLS methodology has been developed and evaluated. Among them, the Etest is the commercial method that has been investigated for the testing of pathogenic yeasts. The Etest method has the advantage of being simple and easy for use $e^{1,19}$. However literature's data comparing MICs obtained by Etest with those obtained by macrodilution or microdilution have shown variable results depending of the antifungal agent and the species tested, as well as on the medium used for testing ${ }^{1,3,19}$. RPMI 1640 medium with $2 \%$ glucose used in our study is the medium recommended for use in the susceptibility testing of yeasts and indicates that medium improves the reprodutibility of the MICs as determined by the Etest ${ }^{3,17}$. Previous comparison by independent laboratories between Etest and broth macrodilution methods, have showed good agreement rates for the azoles and flucytosine, when is used the RPMI $1640^{3,24}$.

In this study we compared the MICs of fluconazole, itraconazole, ketoconazole and amphotericin B by Etest and broth macrodilution techniques against 59 isolates of Candida obtained from patients with AIDS during the initial diagnosis of candidiasis infection. In general, our data showed that there was a good correlation between the MICs obtained by the Etest and broth dilution methods, verifying that both methods showed high MICs values for fluconazole and ketoconazole in Candida isolates. The highest MICs were observed to fluconazole, mainly for $C$. kruse i with $\mathrm{MIC}_{50}$ and $\mathrm{MIC}_{90}>32 \mu \mathrm{g} / \mathrm{mL}$. This specie is considered inherently resistant to fluconazole ${ }^{15}$. Our results are in accordance with others that showed high MIC values for azoles in patients with AIDS $^{22}$. The strains of Candida are generally sensitive to ketoconazole and itraconazole ${ }^{23}$, however in our study $\mathrm{MIC}_{90}$ of ketoconazole for all the species tested were $>32 \mu \mathrm{g} / \mathrm{mL}$ and for itraconazole MIC $_{90}$ was $>32 \mu \mathrm{g} /$ $\mathrm{mL}$ for $C$. krusei. These characteristics can bee explained by the phenomenon of cross-resistance observed among the family of azole compound ${ }^{4}$. Besides, the selection of resistant isolates to azoles would be explained by the long term of azoles in the prophylaxis therapy for patients with $\mathrm{AIDS}^{23}$. When the MIC results at \pm 2 dilutions for both methods were considered, the agreement rates were $90.4 \%$ for itraconazole, ketoconazole and amphotericin B and $84.6 \%$ for fluconazole of the $C$. albicans tested. However, higher discrepancies were noted for C. krusei and C. tropicalis (Table 1). The determination of the endpoints because the usual partial growth inhibition (trailing) observed with azoles was difficult, representing a significant factor in the variability of MIC results for these drugs. As expected, this was a problem with significant number of isolates. The growth of microcolonies inside all of the inhibition zone around the Etest strips was judged in this study to be the most difficult reading pattern.

It is well known that with exception of fluconazole, itraconazole and flucytosine breakpoint concentration have not been defined for other antifungals by the NCCLS. In adition, for fluconazole, these interpretative breakpoints are not aplicable to $C$. krusei, because this specie is assumed to be intrinsically resistant to fluconazole. An analysis of the discrepancies between test methods for fluconazole and itraconazole with NCCLS defined MIC breakpoints showed that the greatest number of very major errors occurred with $C$. albicans isolates tested against fluconazole and with $C$. krusei for itraconazole. These discrepancies in MIC results between the two methods were likely due to the difficulties of consistently reading visual MIC endpoints for isolates which produce trailing growth in the presence of azole antifungal agents. Recently, ST-GERMAIN ${ }^{21}$ emphasized that trailing growth occur mainly with $C$. albicans and $C$. tropicalis. POSTERARO et al. ${ }^{14}$ related that the Etest failed to provide conclusive data on the fluconazole susceptibility of certain isolates of $C$. parapsilosis .

In summary, we obtained a good agreement between the Etest and the broth dilution methods for the drugs susceptibility testing of Candida when endpoints determinations were recorded after 24 hours of incubation for the Etest and 48 hours of incubation for the broth macrodilution.

In conclusion, considering the high concordance of the results of both test systems, Etest could be considered useful for antifungal sensivity evaluation of yeasts in clinical laboratories.

\section{RESUMO}

\section{Avaliação dos métodos de suscetibilidade antifúngica: Etest e macrodiluição em caldo para leveduras do gênero Candida isoladas da cavidade bucal de pacientes com AIDS}

Foram comparados dois testes de suscetibilidade in vitro, macrodiluição em caldo e Etest através da determinação das concentrações inibitórias mínimas de fluconazol, cetoconazol, itraconazol e anfotericina B para 59 isolados de Candida obtidos da cavidade bucal de pacientes com AIDS. O método de Etest foi feito de acordo com as instruções do fabricante e o método de macrodiluição em caldo foi realizado seguindo as normas do NCCLS (National Committee for Clinical Laboratoratory Standards), documento M27-A, considerado método de referência. Nossos dados mostraram uma boa correlação entre os valores de concentração inibitória mínima encontrados para o Etest e o método de macrodiluição em caldo. Foi verificada concordância entre os resultados de CIM, de 90,4\% para itraconazol, cetoconazol e anfotericina B e de $84,6 \%$ para fluconazol, quando se analisou isolados de C. albicans. A comparação de breakpoints mostrou que havia quatro grandes discrepâncias de resultados entre os dois métodos, sendo que pelo método de referência três isolados de Candida albicans classificados como resistentes ao fluconazol e um de C. krusei considerado resistente ao itraconazol foram sensíveis ao Etest. Estes resultados mostraram que o Etest é de grande valor nos testes de suscetibilidade antifúngica para leveduras do gênero Candida. 


\section{REFERENCES}

1. COLOMBO, A.L.; BARCHIESI, F.; McGOUGH, D.A. \& RINALDI, M.G. - Comparison of Etest and National Committee for Clinical Laboratory Standards broth macrodilution method for azole antifungal susceptibility testing. J. clin. Microbiol., 33: 535-540, 1995.

2. ESPINEL-INGROFF, A. - Etest for antifungal susceptibility testing of yeasts. Diagn. Microbiol. infect. Dis., 19: 217-220, 1994.

3. ESPINEL-INGROFF, A.; PFALLER, M.A.; ERWIN, M.E. \& JONES, R.N. Interlaboratory evaluation of Etest method for testing antifungal susceptibilities of pathogenic yeasts to five antifungal agents by using Casitone agar and solidified RPMI 1640 medium with 2\% glucose. J. clin. Microbiol., 34: 848-852, 1996.

4. DUN, E. - Antifungal resistance in yeast vaginitis. Yale J. biol. Med., 72: 281-285, 1999.

5. FROMTLING, R.A.; GALGIANI, J.N.; PFALLER, M.A. et al. - Multicenter evaluation of a broth macrodilution antifungal susceptibility test for yeasts. Antimicrob. Agents Chemother., 37: 39-45, 1993.

6. JORGENSEN, J.H. - Selection criteria for an antimicrobial susceptibility testing system. J. clin. Microbiol., 31: 2841-2844, 1993.

7. KURTZMAN, C.P. \& FELL, J.W. - The yeasts: a taxonomic study. 4. ed. New York, Elsevier, 1998.

8. LOZANO-CHIU, M.; PAETZNICK, V.L.; GHANNOUN, M.A. \& REX, J.H. - Detection of resistance to amphotericin B among Cryptococcus neoformans clinical isolates: performances of three different media assessed by using E-test and National Committee for Clinical Laboratory Standards M27-A methodologies. J. clin. Microbiol., 36: 2817-2822, 1998.

9. MARTINEZ, J. \& ALBRECHT, C. - Sensibilidad al fluconazol y a la anfotericina B en cepas de Candida provenientes de aislamientos clinicos. Rev. iberoamer. Micol., 15: 298-299, 1998

10. NATIONAL COMMITTEE FOR CLINICAL LABORATORY STANDARDS - Reference method for broth dilution antifungal susceptibility testing for yeasts. Proposed Standard. Document M27-P. Villanova, National Committee for Clinical Laboratory Standards, 1992

11. NATIONAL COMMITTEE FOR CLINICAL LABORATORY STANDARDS - Reference method for broth dilution antifungal susceptibility testing for yeasts. Tentative standard M27-T. Villanova, National Committee for Clinical Laboratory Standards, 1995.

12. NATIONAL COMMITTEE FOR CLINICAL LABORATORY STANDARDS - Reference method for broth dilution antifungal susceptibility testing for yeasts; approved standard Document M27-A. Villanova, National Committee for Clinical Laboratory Standards, 1997. v. 17, p. 1-29.
13. PFALLER, M.A.; MESSER, A.S.; BOLMSTROM, A.; ODDS, F.C. \& REX, J.H. Multisite reproducibility of the Etest MIC method for antifungal susceptibility testing of yeast isolates. J. clin. Microbiol., 34: 1691-1693, 1996.

14. POSTERARO, B.; ROMANO, L.; SANGUINETTI, M. et al. - Commercial system for fluconazole susceptibility testing of yeasts: comparison with the broth microdilution method. Diagn. Microbiol. infect. Dis., 38: 29-36, 2000.

15. PRICE, M.F.; La ROCCO, M.T. \& GENTRY, L.O. - Fluconazole susceptibilities of Candida species and distribution of species recovered from blood cultures over a 5year period. Antimicrob. Agents Chemother., 38: 1422-1424, 1994

16. REX, J.H.; PFALLER, M.A.; RINALDI, M.G.; POLAK, A. \& GALGIANI, J.N. Antifungal susceptibility testing. Clin. Microbiol. Rev., 6: 367-381, 1993.

17. RODRÍGUEZ-TUDELA, J.L. \& MARTINEZ-SUÁREZ, J. - Improved medium for fluconazole susceptibility testing of Candida albicans. Antimicrob. Agents Chemother., 38: 45-48, 1994.

18. SANCHEZ, M.L. \& JONES, R.N. - Etest, an antimicrobial susceptibility testing method with broad clinical and epidemiologic application. Antimicrobic Newslett., 8: 1-7, 1992

19. SEWELL, D.L.; PFALLER, M.A. \& BARRY, A.L. - Comparison of broth macrodilution, broth microdilution, and E-test antifungal susceptibility tests for fluconazole. J. clin. Microbiol., 32: 2099-2102, 1994.

20. SILVA, M.R.R. - Variabilidade fenotípica e genotípica de amostras de Candida albicans isoladas da mucosa bucal de pacientes com AIDS. São Paulo, 1999. (Tese de Doutorado - Instituto de Ciências Biomédicas da Universidade de São Paulo).

21. St-GERMAIN, G. - Impact of endpoint definition on the outcome of antifungal susceptibility tests with Candida species: 24-versus 48-h incubation and 50 versus $80 \%$ reduction in growth. Mycoses, 44: 37-45, 2001.

22. TORTORANO, A.M.; VIVIANI, M.A.; BARCHIESI, F. et al. - Comparison of three methods for testing azole susceptibilities of Candida albicans strains isolated sequentially from oral cavities of AIDS patients. J. clin. Microbiol., 36: 1578-1583, 1998.

23. VANDEN BOSSCHE, H. - Mechanisms of antifungal resistance. Rev. iberoamer. Micol., 14: 44-49, 1997.

24. VAN-ELDERE, J.; JOOSTEN, L.; VERHAEGHE, V. \& SURMONT, I. - Fluconazole and amphotericin B antifungal susceptibility testing by National Committee for Clinical Laboratory Standards broth macrodilution method compared with E-test and semiautomated broth microdilution test. J. clin. Microbiol., 34: 842-847, 1996

Received: 15 October 2001

Accepted: 16 April 2002 